\title{
Simple Rational Model for Discharge of Batteries with Aqueous Electrolytes, Based on Nernst Equation
}

\author{
Panagis G. Papadopoulos ${ }^{1}$, Christopher G. Koutitas' \\ Christos G. Karayannis ${ }^{2}$, Panos D. Kiousis ${ }^{3}$, Yannis N. Dimitropoulos ${ }^{4}$ \\ ${ }^{1}$ Department of Civil Engineering, Aristotle University of Thessaloniki, Thessaloniki, Greece \\ ${ }^{2}$ Department of Civil Engineering, Democritus University of Thrace, Xanthi, Greece \\ ${ }^{3}$ Department of Structural and Geotechnical Engineering, Colorado School of Mines, Golden, CO, USA \\ ${ }^{4}$ Department of Chemistry, University of Ioannina, Ioannina, Greece \\ Email: panaggpapad@yahoo.gr
}

How to cite this paper: Papadopoulos, P.G., Koutitas, C.G., Karayannis, C.G., Kiousis, P.D. and Dimitropoulos, Y.N. (2021) Simple Rational Model for Discharge of Batteries with Aqueous Electrolytes, Based on Nernst Equation. Open Journal of Physical Chemistry, 11, $1-11$.

https://doi.org/10.4236/ojpc.2021.111001

Received: December 8, 2020

Accepted: January 31, 2021

Published: February 3, 2021

Copyright $\odot 2021$ by author(s) and Scientific Research Publishing Inc. This work is licensed under the Creative Commons Attribution International License (CC BY 4.0).

http://creativecommons.org/licenses/by/4.0/ (c) (i) Open Access

\begin{abstract}
A simple rational model is proposed for discharge of batteries with aqueous electrolytes, based on Nernst equation. Details of electrode kinetics are not taken into account. Only a few overall parameters of the battery are considered. A simple algorithm, with variable time step-length $\Delta t$, is presented, for proposed model. The model is first applied to Daniel cell, in order to clarify concepts and principles of battery operation. It is found that initial pinching, in time-history curve of voltage $E$ - $t$, is due to initial under-concentration of product ion. Then, model is applied to a lead-acid battery. In absence of an ion product, and in order to construct nominator of Nernst ratio, such an ion, with coefficient tending to zero, is assumed, thus yielding unity in nominator. Time-history curves of voltage, for various values of internal resistance, are compared with corresponding published experimental curves. Temperature effect on voltage-time curve is examined. Proposed model can be extended to other types of batteries, which can be considered as having aqueous electrolytes, too.
\end{abstract}

\section{Keywords}

Battery, Aqueous Electrolyte, Discharge, Nernst Equation, Daniel Cell, Lead-Acid Battery, Temperature Effect

\section{Introduction}

For the discharge of batteries, successful empirical models have been proposed [1]. 
Here, a simple rational model is proposed, based on Nernst equation [2] [3] [4].

Computational analysis of batteries with aqueous electrolytes can be easily implemented, because only aqueous ion concentrations are introduced in Nernst equation.

Here, details of electrode kinetics [5] [6] [7] are not taken into account. Only overall parameters of battery are considered: voltage, capacity, current, concentrations of aqueous ions in reactants and products, internal resistance, volume, temperature, number of electrons involved in chemical reaction.

A simple algorithm, with variable time step-length $\Delta t$, is presented, for proposed model. When exhausting of battery capacity is approached and denominator of Nernst ratio tends to become negative, $\Delta t$ is halved and algorithm step is repeated, as many times are needed for denominator to remain positive.

Proposed model is first applied to Daniel cell [8], in order to clarify concepts and principles of battery operation. It is found that initial pinching of voltage-time curve $E$ - $t$ is due to initial under-concentration of product ion.

Then, model is applied to a lead-acid battery [9]. In absence of an aqueous ion product and in order to construct nominator of Nernst ratio, such an ion is assumed, with coefficient tending to zero, thus yielding unity in nominator.

Time-history curves of voltage $E$ - $t$ of lead-acid battery, for various values of internal resistance, are compared with corresponding published experimental curves [10] and found in satisfactory approximation with them. Temperature effect, on voltage-time curve, is examined.

In future research, proposed model can be extended to other types of batteries, which can be considered as having aqueous electrolytes, too, e.g. redox flow cells [11], vanadium batteries [12], lithium-ion batteries [13], fuel cells [14].

\section{Simple Algorithm for Proposed Model}

For a general form of total chemical reaction of a battery with aqueous electrolyte

$$
a \mathrm{~A}(\mathrm{~s})+b \mathrm{~B}(\mathrm{l})+c \mathrm{C}(\mathrm{aq})+d \mathrm{D}(\mathrm{aq}) \rightarrow e \mathrm{E}(\mathrm{s})+f \mathrm{~F}(\mathrm{l})+g \mathrm{G}(\mathrm{aq})+h \mathrm{H}(\mathrm{aq})
$$

the flow-chart of algorithm of proposed model, for discharge of batteries with aqueous electrolytes, is presented in Figure 1.

First, the physical constants are read: universal gas constant $R=8.314 \mathrm{~J} \cdot \mathrm{mol}^{-1} \cdot \mathrm{K}^{-1}$ and Faraday constant $F=96490 \mathrm{C} \cdot \mathrm{mol}^{-1} \cdot \mathrm{e}^{-1}$, where $\mathrm{e}$ electric charge of an electron.

Then, constant input data are read: nominal voltage $E_{0}$ of battery in $\mathrm{V}$, total capacity $Q_{0}$ in C, internal resistance $r$ in $\Omega$, volume $v$ in L, temperature $T$ in $\mathrm{K}$, number $\mathrm{n}$ of electrons involved in chemical reaction of battery, as well as coefficients $c, d$ of reactant ions and $g, h$ of product ions of Equation (1).

The initial conditions are read: For step number $i=0$, time $t=0$. and discharged capacity $Q=0$., initial concentrations $[\mathrm{C}]_{0},[\mathrm{D}]_{0}$ of reactant ions and $[\mathrm{G}]_{0},[\mathrm{H}]_{0}$ of product ions in mol. $\mathrm{L}^{-1}$, as well as initial time step-length $\Delta \mathrm{t}$ of the algorithm in sec. 


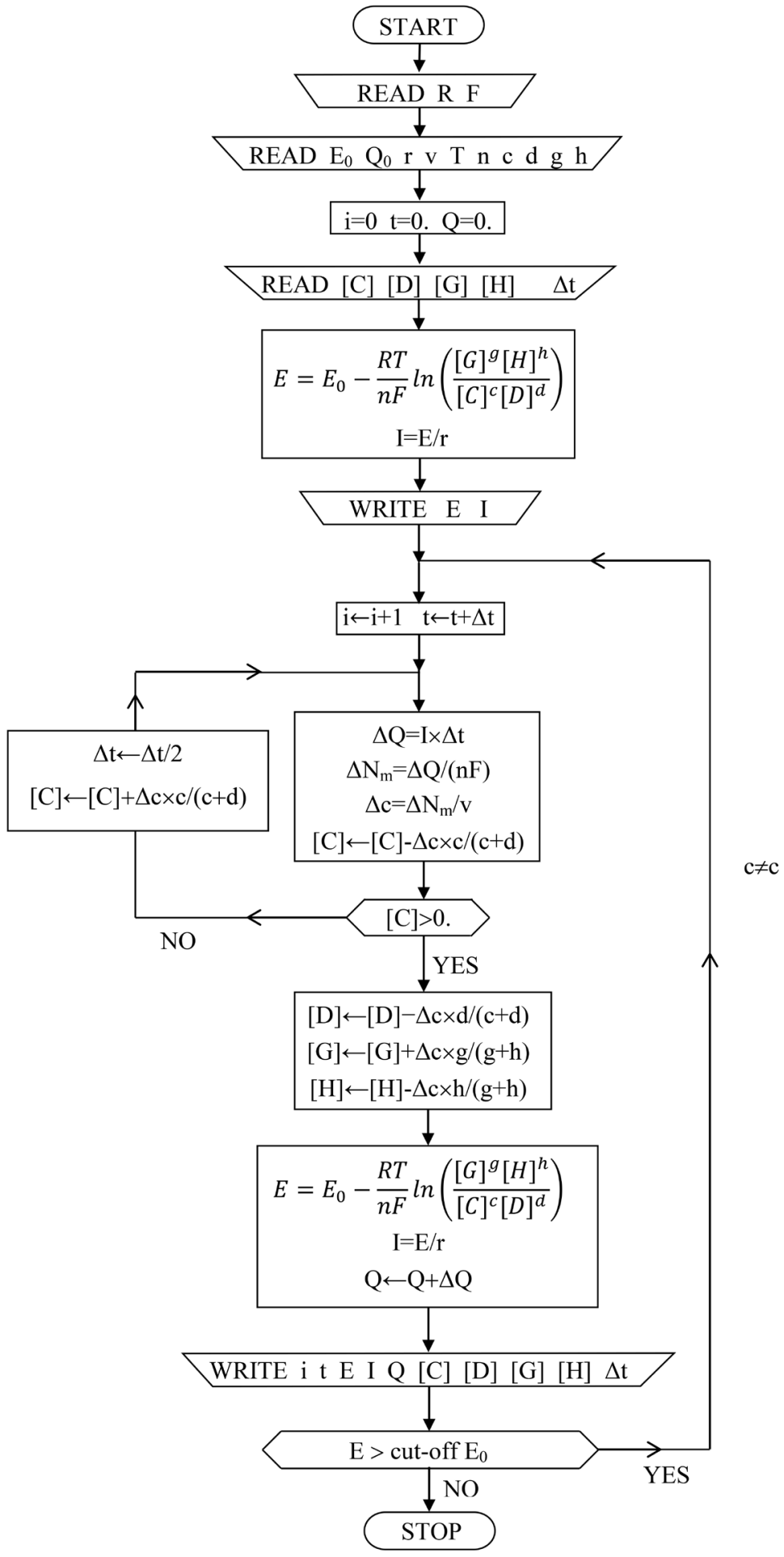

Figure 1. Flow-chart of algorithm of proposed model, for discharge of batteries with aqueous electrolytes.

Then, the initial voltage $E$ in $\mathrm{V}$ is found, by Nernst equation

$$
E=E_{0}-\frac{R T}{n F} \ln \left(\frac{[\mathrm{G}]^{g}[\mathrm{H}]^{h}}{[\mathrm{C}]^{c}[\mathrm{D}]^{d}}\right)
$$


and the initial current $I=E / r$ in A.

For any $i$-th step of the algorithm, first step number $i$ is increased by 1 and time $t$ by $\Delta t$.

Then, the transferred electric charge increment $\Delta Q=I \times \Delta t$ in $\mathrm{C}$, within present step, is determined. From this $\Delta Q$, the corresponding increment of number of moles is found $\Delta N_{m}=\Delta Q /(n F)$ and the transferred concentration increment $\Delta c=\Delta N_{m} / v$ in $\mathrm{mol} \cdot \mathrm{L}^{-1}$.

This concentration increment $\Delta c$ will be distributed to reactant and product ions, proportionally to their coefficients:

$$
\begin{aligned}
& \text { Reactants }[\mathrm{C}] \leftarrow[\mathrm{C}]-\frac{c}{c+d} \Delta c,[\mathrm{D}] \leftarrow[\mathrm{D}]-\frac{d}{c+d} \Delta c \\
& \text { Products }[\mathrm{G}] \leftarrow[\mathrm{G}]+\frac{g}{g+h} \Delta c,[\mathrm{H}] \leftarrow[\mathrm{H}]+\frac{h}{g+h} \Delta c
\end{aligned}
$$

However, previously, the reactant which is going to be first consumed, let $\mathrm{C}$ here, is checked if its concentration becomes negative in present step. In such a case, $[\mathrm{C}]$ is restored to its previous value $\left([\mathrm{C}] \leftarrow[\mathrm{C}]-\frac{c}{c+d} \Delta c\right), \Delta t$ is halved $\Delta t \leftarrow \Delta t / 2$ and algorithm step is repeated as many times are needed, in order for [C] to become positive. (This procedure occurs when capacity tends to be exhausted $Q \leftarrow Q_{0}$ and abrupt drop of voltage $E$ starts).

After updating of concentrations of reactant and product ions, the new voltage is found by Nernst equation

$$
E=E_{0}-\frac{R T}{n F} \ln \left(\frac{[\mathrm{G}]^{g}[\mathrm{H}]^{h}}{[\mathrm{C}]^{c}[\mathrm{D}]^{d}}\right),
$$

new current $I=E / r$ and new discharged capacity $Q \leftarrow Q+\Delta Q$ are determined.

As output of present step of algorithm, the following data are written: number $i$ of algorithm step, time $t$, voltage $E$, current $I$, discharged capacity $Q$, concentrations of reactant ions $[\mathrm{C}],[\mathrm{D}]$ and product ions $[\mathrm{G}],[\mathrm{H}]$, present time step-length $\Delta t$.

At end of present step of algorithm, if voltage $E$ is still greater than the desired cut-off voltage, e.g. $0.5 E_{0}$ or $0.8 E_{0}$, we go to next step of algorithm. Otherwise, algorithm is interrupted.

Based on above simple algorithm, a short computer program has been developed, with only fifty five Fortran instructions, for discharge of batteries with aqueous electrolytes.

\section{Application to Daniel Cell}

The proposed model is first applied to Daniel cell, in order to clarify concepts and principles of battery operation. In Figure 2, the sketch of a Daniel cell is presented [8].

A container is divided, by a porous diaphragm, into two compartments. The left compartment is filled by an aqueous electrolyte of sulfuric zinc $\mathrm{ZnSO}_{4}(\mathrm{aq})$ 
and the right one is filled by sulfuric copper $\mathrm{CuSO}_{4}(\mathrm{aq})$. In the left compartment, a zinc electrode $\mathrm{Zn}(\mathrm{s})$ is dipped and, in the right one, a copper electrode $\mathrm{Cu}(\mathrm{s})$. The upper ends of two electrodes, outside of the container, are connected by an external wire with resistance $r$. Because of potential difference, at $25^{\circ} \mathrm{C}$, $E_{0}=+0.34-(-0.76)=1.10 \mathrm{~V}$ [4], between upper ends of two electrodes, electrons flow through the wire, from left $\mathrm{Zn}$ electrode to right $\mathrm{Cu}$ electrode.

In the left zinc electrode, because of subtraction of electrons, zinc cations $\mathrm{Zn}^{2+}$ are repelled from $\mathrm{Zn}(\mathrm{s})$ to electrolyte $\mathrm{ZnSO}_{4}$ (aq). Whereas, in the right copper electrode, because of addition of electrons, copper cations $\mathrm{Cu}^{2+}$ from electrolyte $\mathrm{CuSO}_{4}(\mathrm{aq})$ are attracted to electrode $\mathrm{Cu}(\mathrm{s})$ (Figure 2).

The vertical porous diaphragm, in the middle of container, prevents passage of metal cations $\mathrm{Zn}^{2+}$, $\mathrm{Cu}^{2+}$, but allows passage of anion $\mathrm{SO}_{4}^{2-}$ [8]. So, from right compartment, where there is an excess of anions $\mathrm{SO}_{4}^{2-}$, after attraction of $\mathrm{Cu}^{2+}$ by $\mathrm{Cu}(\mathrm{s})$ electrode, free anions $\mathrm{SO}_{4}^{2-}$ pass, through porous diaphragm, to left compartment, where there is an excess of $\mathrm{Zn}^{2+}$ cations, after their repel from electrode $\mathrm{Zn}(\mathrm{s})$, so that free $\mathrm{SO}_{4}^{2-}$ anions meet free $\mathrm{Zn}^{2+}$ cations, in order to close the circuit and maintain electro-neutrality (Figure 2).

So, chemical reactions of Daniel cell are the following:

In left compartment, oxidation half-reaction

$$
\mathrm{Zn}(\mathrm{s})-2 \mathrm{e}^{-} \rightarrow \mathrm{Zn}^{2+}(\mathrm{aq}),
$$

with $E_{0}=-0.76 \mathrm{~V}$, from table of standard reduction potentials at $25^{\circ} \mathrm{C}$ [4].

In right compartment, reduction half-reaction

$$
\mathrm{Cu}^{2+}(\mathrm{aq})+2 \mathrm{e}^{-} \rightarrow \mathrm{Cu}(\mathrm{s})
$$

with $E_{0}=+0.34 \mathrm{~V}$.

By adding the above two half-reactions, total chemical reaction of Daniel cell is obtained

$$
\mathrm{Zn}(\mathrm{s})+\mathrm{Cu}^{2+}(\mathrm{aq}) \rightarrow \mathrm{Zn}^{2+}(\mathrm{aq})+\mathrm{Cu}(\mathrm{s})
$$

with $E_{0}=+0.34-(-0.76)=+1.10 \mathrm{~V}$.

If, for a Daniel cell, is chosen capacity $\mathrm{Q}_{0}=1.0 \mathrm{~A} \cdot \mathrm{h}=3600 \mathrm{C}$ and initial concentration of reactant ion $\left[\mathrm{Cu}^{2+}(\mathrm{aq})\right]_{0}=1.0 \mathrm{~mol} \cdot \mathrm{L}^{-1}$, this choice implies a specific value of battery volume $v$, which is simply determined as follows:

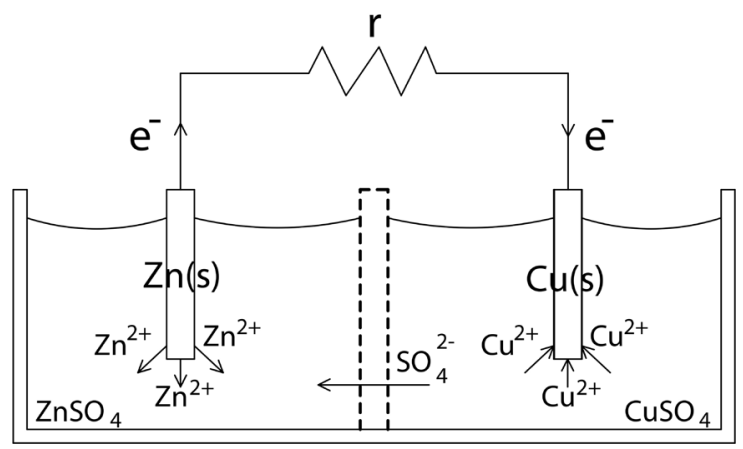

Figure 2. Operation of Daniel cell. 


$$
\begin{gathered}
{\left[\mathrm{Cu}^{2+}(\mathrm{aq})\right]_{0} \times v \times n \times F=Q_{0}} \\
1.0 \mathrm{~mol} \cdot \mathrm{L}^{-1} \times v \times 2 \mathrm{e} \times 96490 \mathrm{C} \cdot \mathrm{mol}^{-1} \cdot \mathrm{e}^{-1}=3600 \mathrm{C} \\
\rightarrow v=0.01865 \mathrm{~L}=18.65 \mathrm{~cm}^{3}
\end{gathered}
$$

corresponding to a cube with side $a=2.652 \mathrm{~cm}$.

If it is further assumed that, in this Daniel cell, initial concentration of product ion is very small $\left[\mathrm{Zn}^{2+}(\mathrm{aq})\right]_{0}=10^{-5} \mathrm{~mol} \cdot \mathrm{L}^{-1}$, the initial voltage, at $25^{\circ} \mathrm{C}$, results, according to Nernst equation:

$$
\begin{gathered}
E=E_{0}-\frac{R T}{n F} \ln \left(\frac{\left[\mathrm{Zn}^{2+}\right]_{0}}{\left[\mathrm{Cu}^{2+}\right]_{0}}\right), \\
E=1.10 \mathrm{~V}-\frac{8.314 \mathrm{~J} \cdot \mathrm{mol}^{-1} \cdot \mathrm{K}^{-1} \times 298 \mathrm{~K}}{2 \mathrm{e} \times 96490 \mathrm{C} \cdot \mathrm{mol}^{-1} \cdot \mathrm{e}^{-1}} \ln \left(\frac{10^{-5}}{1.0}\right) \\
=1.10 \mathrm{~V}-0.01284 \frac{\mathrm{J}}{\mathrm{C}} \times(-11.51) \\
=1.10 \mathrm{~V}+0.1478 \mathrm{~V}=1.248 \mathrm{~V}
\end{gathered}
$$

That is, an initial voltage, by $0.1478 \mathrm{~V}$, higher than nominal voltage $E_{0}=1.10 \mathrm{~V}$, is obtained. So, it is observed that initial pinching of voltage is due to initial under-concentration of product ion $\left[\mathrm{Zn}^{2+}(\mathrm{aq})\right]_{0}=10^{-5} \mathrm{~mol} \cdot \mathrm{L}^{-1}$.

The above Daniel cell can run by the proposed algorithm of Figure 1. The constant input data are: nominal voltage $E_{0}=1.10 \mathrm{~V}$, total capacity $Q_{0}=3600 \mathrm{C}$, three values of internal resistance $r$ will be tried, 11., 5.5, $1.1 \Omega$, volume $v=0.01865$ $\mathrm{L}$, temperature $T=298 \mathrm{~K}$, number of electrons involved in chemical reaction $n=$ 2. Coefficients of reaction: reactant ions $c=1, d=0$, product ions $g=1, h=0$, according to Equation (1). The initial conditions are: concentration of reactant ion $\left[\mathrm{Cu}^{2+}(\mathrm{aq})\right]_{0}=1.0 \mathrm{~mol} \cdot \mathrm{L}^{-1}$, of product ion $\left[\mathrm{Zn}^{2+}(\mathrm{aq})\right]_{0}=10^{-5} \mathrm{~mol} \cdot \mathrm{L}^{-1}$. For initial time step-length $\Delta t$, three values are used: $3600,1800,360 \mathrm{sec}$, corresponding to the three resistances $r .11,5.5,1.1 \Omega$.

The proposed algorithm of Figure 1 run with above input data and gave output data, on the basis of which, time-histories for the three resistances $r .11,5.5$, $1.1 \Omega$, have been drawn; curves $E$ - $t$ for voltage in Figure 3(a) and curves $I-t$ for current in Figure 3(b).

It is observed, in Figure $3(\mathrm{~b})$, that, for every $I-t$ curve, area $\int_{0}^{t} I \mathrm{~d} t$ equals discharged capacity $Q(t)$ for time $t$, whereas area $\int_{0}^{t_{u}} I \mathrm{~d} t$ equals total capacity $Q_{0}$ of battery, where $t_{u}$ duration of battery, as was expected.

\section{Application to Lead-Acid Battery}

Lead-acid battery is an old type of battery, which is still used in many applications [9].

The oxidation half-reaction of a lead-acid cell is

$$
\mathrm{Pb}(\mathrm{s})+\mathrm{HSO}_{4}^{-}(\mathrm{aq})-2 \mathrm{e}^{-} \rightarrow \mathrm{PbSO}_{4}(\mathrm{~s})+\mathrm{H}^{+}(\mathrm{aq}),
$$

with $E_{0}=-0.36 \mathrm{~V}$. 


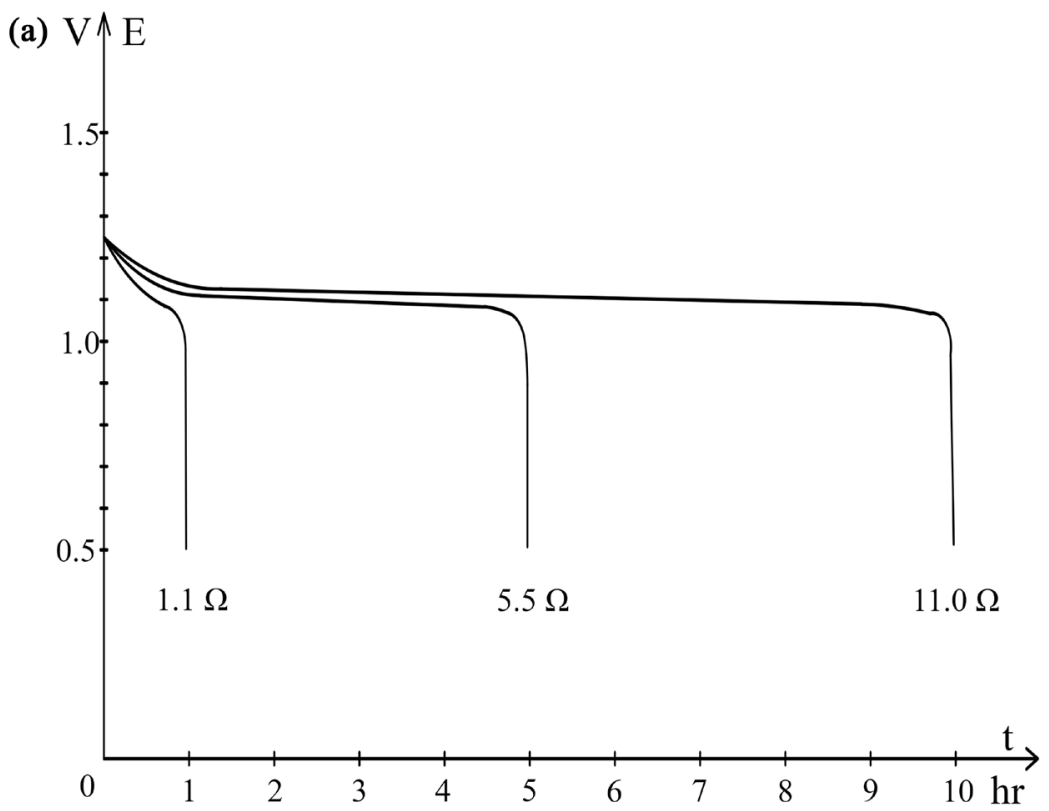

(b)

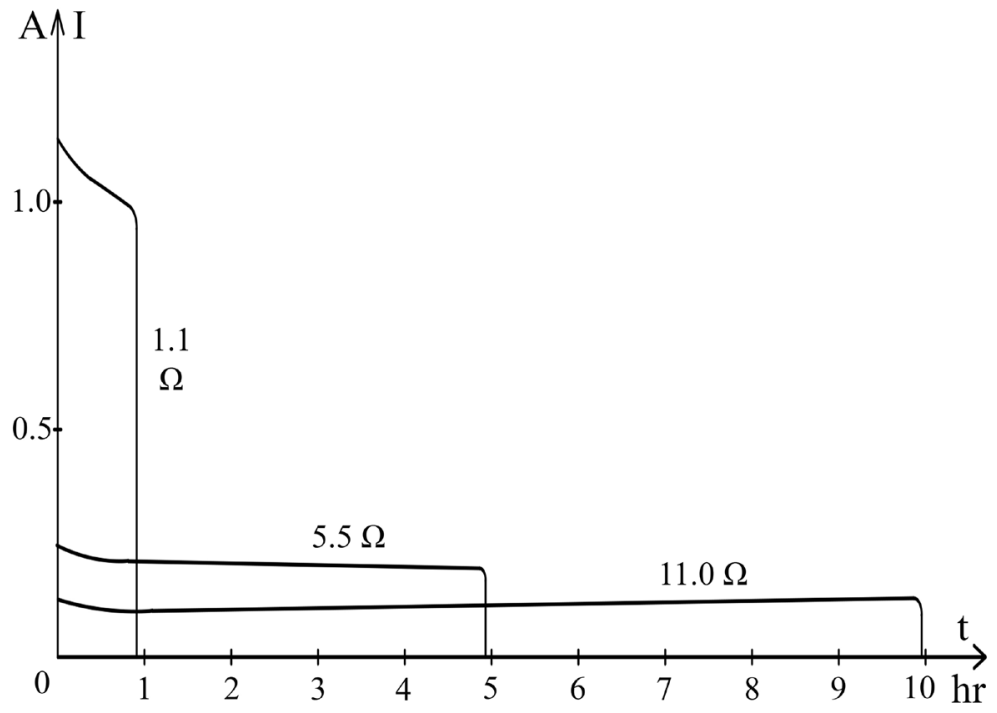

Figure 3. For a Daniel cell with nominal voltage $E_{0}=1.10 \mathrm{~V}$, total capacity $Q_{0}=1.0 \mathrm{Ah}$, volume $v=18.65 \mathrm{~cm}^{3}$, temperature $T=25^{\circ} \mathrm{C}$, initial concentration of reactant ion $\left[\mathrm{Cu}^{2+}\right]_{0}$ $=1.0 \mathrm{~mol} \cdot \mathrm{L}^{-1}$, of product ion $\left[\mathrm{Zn}^{2+}\right]_{0}=10^{-5} \mathrm{~mol} \cdot \mathrm{L}^{-1}$, for three values of resistance $r .11$., $5.5,1.1 \Omega$, diagrams obtained by proposed model. (a) Time-histories of voltage $E$ - $t$. (b) Time-histories of current $I-t$.

and the reduction half-reaction

$$
\mathrm{PbO}_{2}(\mathrm{~s})+\mathrm{HSO}_{4}^{-}(\mathrm{aq})+3 \mathrm{H}^{+}(\mathrm{aq})+2 \mathrm{e}^{-} \rightarrow \mathrm{PbSO}_{4}(\mathrm{~s})+2 \mathrm{H}_{2} \mathrm{O}(\mathrm{l})
$$

with $E_{0}=+1.69 \mathrm{~V}$.

So, the total chemical reaction of the cell is

$$
\mathrm{Pb}(\mathrm{s})+\mathrm{PbO}_{2}(\mathrm{~s})+2 \mathrm{H}^{+}(\mathrm{aq})+2 \mathrm{HSO}_{4}^{-}(\mathrm{aq}) \rightarrow 2 \mathrm{PbSO}_{4}(\mathrm{~s})+2 \mathrm{H}_{2} \mathrm{O}(\mathrm{l})
$$

with $E_{0}=+1.69-(-0.36)=2.05 \mathrm{~V}$.

In the absence of an aqueous ion among products, and in order to construct 
nominator of Nernst ratio, such an ion $\mathrm{P}(\mathrm{aq})$, with coefficient tending to zero, let $10^{-5}$, is assumed, thus yielding unity in nominator $[\mathrm{P}(\mathrm{aq})]^{0}=1.0$.

So, total reaction becomes

$$
\begin{aligned}
& \mathrm{Pb}(\mathrm{s})+\mathrm{PbO}_{2}(\mathrm{~s})+2 \mathrm{H}^{+}(\mathrm{aq})+2 \mathrm{HSO}_{4}^{-}(\mathrm{aq}) \\
& \rightarrow 2 \mathrm{PbSO}_{4}(\mathrm{~s})+2 \mathrm{H}_{2} \mathrm{O}(\mathrm{l})+10^{-5} \mathrm{P}(\mathrm{aq})
\end{aligned}
$$

and the Nernst equation becomes

$$
E=E_{0}-\frac{R T}{n F} \ln \left(\frac{1.0}{\left[\mathrm{H}^{+}\right]^{2}\left[\mathrm{HSO}_{4}^{-}\right]^{2}}\right)
$$

All concentrations of reactant ions are gradually transformed to concentration of product ion $[\mathrm{P}(\mathrm{aq})]$, which, however, has meaningless participation in chemical reaction.

Here, a battery, consisting of three lead-acid cells, is considered, so nominal voltage is $E_{0}=3 \times 2.05 \mathrm{~V}=6.15 \mathrm{~V} \approx 6.20 \mathrm{~V}$.

If a total initial capacity $Q_{0}=1.0 \mathrm{~A} \cdot \mathrm{h}=3600 \mathrm{C}$ of the battery is chosen and initial concentrations of reactant ions $\left[\mathrm{H}^{+}\right]_{0}=\left[\mathrm{HSO}_{4}^{-}(\mathrm{aq})\right]_{0}=1.0 \mathrm{~mol} \cdot \mathrm{L}^{-1}$, this choice implies a specific value of battery volume $\mathrm{v}$, which is simply determined as follows:

$$
\begin{gathered}
\left(\left[\mathrm{H}^{+}\right]_{0}+\left[\mathrm{HSO}_{4}^{-}\right]_{0}\right) \times v \times n \times F=Q_{0} \\
2.0 \mathrm{~mol} \cdot \mathrm{L}^{-1} \times v \times 2 \mathrm{e} \times 96490 \mathrm{C} \cdot \mathrm{mol}^{-1} \cdot \mathrm{e}^{-1}=3600 \mathrm{C} \\
\rightarrow v=9.3274 \times 10^{-3} \mathrm{~L}=9.3274 \mathrm{~cm}^{3}
\end{gathered}
$$

corresponding to a cube with side $a=2.105 \mathrm{~cm}$

The above lead-acid battery can run with the algorithm of Figure 1, with the following input. Constant input data: nominal voltage $E_{0}=6.20 \mathrm{~V}$, total capacity $Q_{0}=3600$ C , for internal resistance $\mathrm{r}$ five values will be tried: 62.0, 31.0, 18.6, 6.2, $2.067 \Omega$, volume $v=9.3274 \times 10^{-3} \mathrm{~L}$, temperature $T=298 \mathrm{~K}$, number of electrons involved in chemical reaction $n=2$, coefficients in chemical reaction, of reactants $c=d=2.0$, of products $g=10^{-5}, h=0$, according to Equation (1). Initial conditions: concentrations of reactant ions $\left[\mathrm{H}^{+}\right]_{0}=\left[\mathrm{HSO}_{4}^{-}\right]_{0}=1.0 \mathrm{~mol} \cdot \mathrm{L}^{-1}$, of product ion $[\mathrm{P}(\mathrm{aq})]_{0}=10^{-3} \mathrm{~mol} \cdot \mathrm{L}^{-1}$, for initial time step-length $\Delta t$ five values will be used: $3600,1800,1080,360,120 \mathrm{sec}$ corresponding to the five resistances $r .62$., 31., 18.6, 6.2, $2.067 \Omega$.

The proposed algorithm of Figure 1 run with the above input data and gave output data, on the basis of which, time-histories, corresponding to the five resistances $r$, are obtained.

In Figure 4(a), the time-histories of voltage $E$ - $t$ for the five resistances $r$, obtained by proposed model, are compared to corresponding published experimental curves $E-t[10]$ and the approximation, between them, can be considered satisfactory.

Then, for the same lead-acid battery, temperature effect on time-history of voltage $E-t$ is examined. For internal resistance $r=31.0 \Omega$ and three values of 
(a)

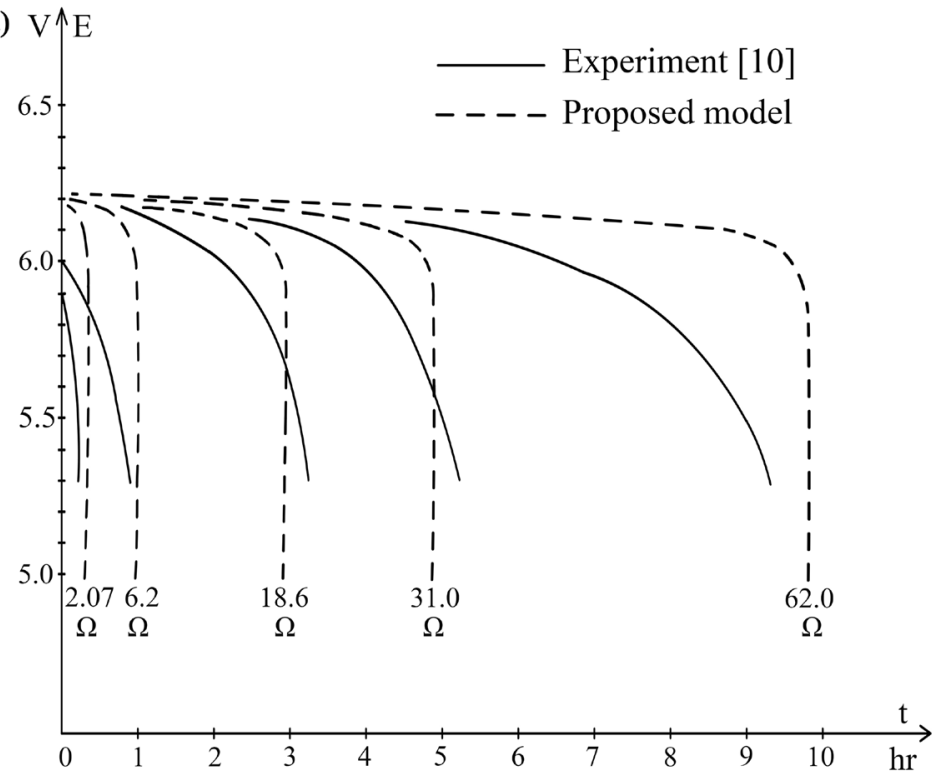

(b)

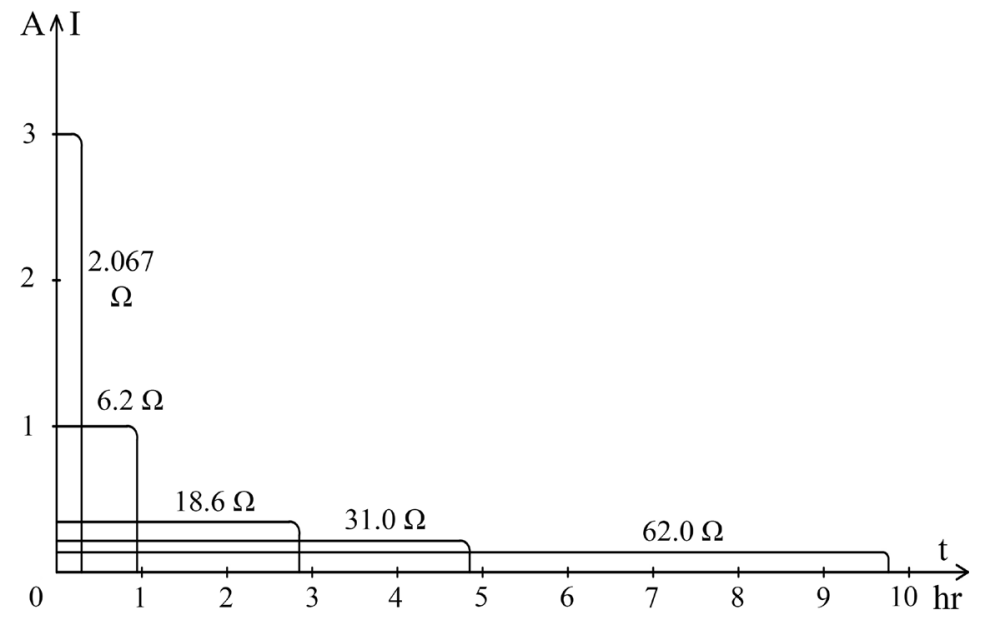

Figure 4. For a lead-acid battery with nominal voltage $E_{0}=6.20 \mathrm{~V}$, total capacity $Q_{0}=1.0$ Ah, volume $V=9.325 \mathrm{~cm}^{3}$, temperature $T=25^{\circ} \mathrm{C}$, initial concentrations of reactant ions $\left[\mathrm{H}^{+}\right]=\left[\mathrm{HSO}_{4}^{-}\right]=1.0 \mathrm{~mol} \cdot \mathrm{L}^{-1}$, for five values of resistance $r .62 ., 31 ., 18.6,6.2,2.067 \Omega$.

(a) Time-histories of voltage $E$ - $t$, obtained by proposed model, compared with corresponding published experimental curves [10]. (b) Time-histories of current $I$ - $t$ obtained by proposed model.

temperature $T: 10^{\circ} \mathrm{C}=283 \mathrm{~K}, 50^{\circ} \mathrm{C}=323 \mathrm{~K}, 90^{\circ} \mathrm{C}=363 \mathrm{~K}$, the three corresponding curves for time-history of voltage $E$ - $t$ have been drawn in Figure 5 . It is observed that, as temperature $T$ increases, voltage $E$ decreases. Whereas, for increasing temperature, duration $t_{u}$ of battery slightly increases.

For the temperature $T$ values tried here, effect of temperature on voltage $E$ is not significant; variations up to $0.035 \mathrm{~V}$ only are observed.

\section{Conclusions}

1) A simple rational (not empirical) model is proposed, for discharge of batteries with aqueous electrolytes, based on Nernst equation. 


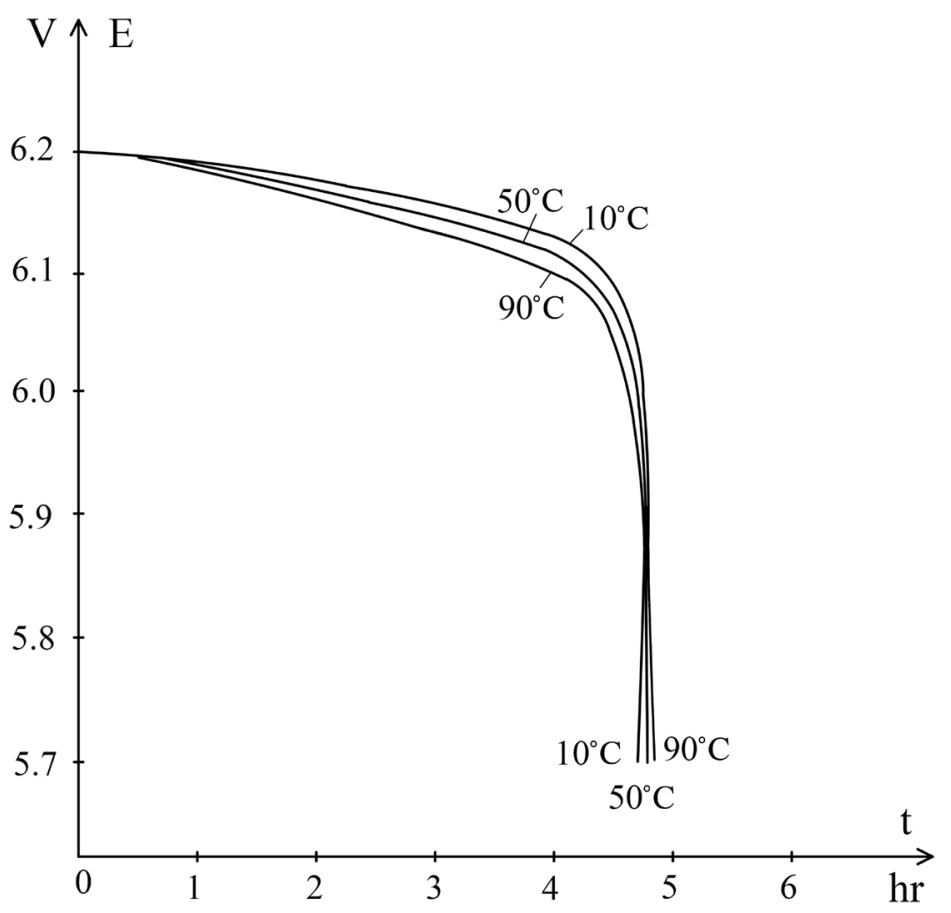

Figure 5. For the same battery of Figure 4, for resistance $r=31 \Omega$ and three values of temperature $T: 10^{\circ} \mathrm{C}, 50^{\circ} \mathrm{C}, 90^{\circ} \mathrm{C}$, time-histories of voltage $E$ - $t$ obtained by proposed model.

2) Details of electrode kinetics are not taken into account. Only a few overall parameters of the battery are considered.

3) A simple algorithm is presented, for proposed model, with variable time step-length $\Delta t$, describing both regions of the $E$ - $t$ curve, that with slow reduction of voltage, as well as that with abrupt reduction.

4) Proposed model is first applied to Daniel cell, in order to clarify concepts and principles of battery operation.

5) It is found that initial pinching, in time-history curve of voltage, is due to initial under-concentration of product ions.

6) As in the chemical reaction of a lead-acid battery, no product aqueous ion exists, such an ion, with coefficient tending to zero, is considered, yielding unity in the nominator of Nernst ratio.

7) Time-history curves of voltage of a lead-acid battery, for five values of resistance, obtained by proposed model, are compared with corresponding published experimental curves.

8) Effect of temperature, on time-history of voltage, is examined.

9) Proposed model can be extended to other types of batteries, which can be considered as having aqueous electrolytes, too.

\section{Conflicts of Interest}

The authors declare no conflicts of interest regarding the publication of this paper. 


\section{References}

[1] Füller, M.E. (2012) Generic Battery Rate Effect Model. Naval Undersea Warfare Center Division, Newport, Rhode Island, USA, Report Number TM 12-052. https://apps.dtic.mil/dtic/tr/fulltext/u2/a567756.pdf

[2] Vincent, C.A. and Scrosati, B. (1997) Modern Batteries. An Introduction to Electrochemical Power Sources. 2nd Edition, Butterworth-Heinemann Elsevier Ltd, Oxford. https://doi.org/10.1016/B978-034066278-6/50002-4

[3] Reddy, T.B. (2011) Linden's Handbook of Batteries, Fourth Edition. McGraw-Hill. https://www.accessengineeringlibrary.com/content/book/9780071624213

[4] Brady, J.E., Russell, J.W. and Holum, J.R. (2000) Chemistry: Matter and Its Changes. 3rd Edition, Wiley, Hoboken.

[5] Lefrou, C., Fabry, P. and Poignet, J.-C. (2012) Electrochemistry. The Basics with Examples. Springer, New York. https://doi.org/10.1007/978-3-642-30250-3

[6] Wikipedia (2020) Butler-Volmer Equation. https://en.wikipedia.org/wiki/Butler\%E2\%80\%93Volmer equation

[7] Wikipedia (2020) Tafel Equation. https://en.wikipedia.org/wiki/Tafel equation

[8] Wikipedia (2020) Galvanic Cell. https://en.wikipedia.org/wiki/Galvanic cell

[9] Wikipedia (2020) Lead-Acid Battery. https://en.wikipedia.org/wiki/Lead\%E2\%80\%93acid battery

[10] Hariprakash, B., Mane, A.U., Martha, S.K., Gaffoor, S.A., Shivashankar, A. and Shukla, A.K. (2004) A Low Cost, High Energy-Density Lead/Acid Battery. Electrochemical and Solid State Letters, 7, A66-A69. https://doi.org/10.1149/1.1645752

[11] Chen, R., Kim, S. and Chang, Z. (2017) Redox Flow Batteries: Fundamentals and Applications. InTechOpen 68752, Chapter 5, 103-118. https://doi.org/10.5772/intechopen.68752

[12] Zeng, S., Zeng, L., Wang, R., Guo, W. and Tang, H. (2018) Effect of Elevated Temperature Annealing on Nafion $/ \mathrm{SiO}_{2}$ Composite Membranes for the All-Vanadium Redox Flow Battery. Polymers, 10, 473. https://doi.org/10.3390/polym10050473

[13] Huang, Q., Li, H., Gratsel, M. and Wang, Q. (2013) Reversible Chemical Delithiation/Lithiation of $\mathrm{LiFePO}_{4}$ : Towards a Redox Flow Lithium-Ion Battery. Physical Chemistry Chemical Physics, 15, 1793-1797. https://doi.org/10.1039/C2CP44466F

[14] Wikipedia (2020) Fuel Cell. https://en.wikipedia.org/wiki/Fuel cell 